\title{
Strategi Komunikasi untuk Program Corporate Social Responsibility dalam Pemberdayaan Masyarakat
}

\author{
Arifin Saleh $^{1}$, Mislan Sihite ${ }^{2}$ \\ ${ }^{1}$ Universitas Muhammadiyah Sumatera Utara, Medan, Indonesia \\ ${ }^{2}$ Universitas Methodist Indonesia, Medan, Indonesia \\ email: arifinsaleh@umsu.ac.id
}

\begin{abstract}
Corporate social responsibility (CSR) is a company's commitment not only to increase financial benefits, but also to develop a holistic, institutional and sustainable social, economic and regional development (Suharto, 2008). In practice, CSR is often regarded as corporate giving, corporate philanthropy, and corporate community relations. CSR cannot be separated from the practice of community empowerment or often referred to as community development. What is the relationship between CSR and community empowerment and how is the communication strategy for the CSR program in an effort to empower the community? The methodology in this study is of literature review type. The technique of data collection is done by secondary data techniques obtained through searching relevant books, research results related to the topic of writing, mass media news, and relevant journals. The data obtained are then analyzed and completed with qualitative techniques by describing the data obtained to answer the existing debate. The results of the study found that CSR programs cannot be separated from community empowerment. One of the objectives of CSR is to create empowered communities, especially those around the company. In carrying out CSR activities for community empowerment, the role of a communication strategy is expected. The relevant communication strategies include mass communication and intercultural communication. By using these two communication strategies, it is expected that CSR programs for community empowerment will be more effective and efficient.
\end{abstract}

\section{Keyword: Corporate Social Responsibility, Community Development, Mass Communication and Intercultural Communication}

\section{ABSTRAK}

Corporate social responsibility (CSR) atau tanggung jawab sosial perusahaan adalah komitmen perusahaan yang tidak hanya untuk meningkatkan keuntungan secara finansial, tetapi juga untuk pembangunan sosial, ekonomi kawasan secara holistik, melembaga, dan berkelanjutan (Suharto, 2008). Dalam praktiknya, CSR sering diangap sebagai corporate giving, corporate philanthropy, dan corporate community relations. CSR tidak bisa dilepaskan dari praktik pemberdayaan masyarakat atau sering disebut dengan istilah community development. Bagaimanakah hubungan CSR dengan pemberdayaan masyarakat dan bagaimanakah strategi komunikasi untuk program CSR dalam upaya pemberdayaan masyarakat?. Metodologi dalam kajian ini berjenis berjenis telaah pustaka yang disajikan secara diskriptif. Teknik pengumpulan datanya dilakukan dengan teknik data sekunder yang diperoleh melalui penelusuran buku-buku yang relevan, hasil penelitian yang terkait dengan topik tulisan, berita media massa, dan jurnal-jurnal yang relevan. Data-data yang diperoleh tersebut selanjutnya dianalisis dan dibahas dengan teknik kualitatif dengan pendiskripsian data-data yang diperoleh untuk menjawab permasalahan yang ada. Hasil kajian menemukan 
bahwa program CSR tak bisa dilepaskan dari pemberdayaan masyarakat. Tujuan CSR salah satunya adalah untuk mewujudkan masyarakat berdaya, khususnya masyarakat yang ada di sekitar perusahaan. Dalam melaksanakan kegiatan CSR untuk pemberdayaan masyarakat, peran strategy komunikasi sangat diharapkan. Strategi komunikasi yang relevan antara lain adalah lewat komunikasi massa dan komunikasi antarbudaya. Dengan pengunaan dua strategi komunikasi ini diharapkan program-program CSR untuk pemberdayaan masyarakat lebih efektif dan efesien.

Kata Kunci: Tanggung Jawab Sosial Perusahaan, Pemberdayaan Masyarakat, Komunikasi Massa dan Komunikasi Antarbudaya

\section{Pendahuluan}

Corporate social responsibility (CSR) atau tanggung jawab sosial perusahaan adalah komitmen perusahaan yang tidak hanya untuk meningkatkan keuntungan secara finansial, tetapi juga untuk pembangunan sosial, ekonomi kawasan secara holistik, melembaga, dan berkelanjutan (Suharto, 2008). Dalam praktiknya, CSR sering diangap sebagai corporate giving, corporate philanthropy, dan corporate community relations.

Secara konsep maupun praktik, CSR tidak bisa dilepaskan dari praktik pemberdayaan masyarakat atau sering disebut dengan istilah community development. Seringkali kegiatan- kegiatan CSR, khususnya di bidang sosial dan ekonomi diarahkan kepada pemberdayaan masyarakat. Demikian sebaliknya, dalam kegiatan pemberdayaan masyarakat tak jarang selalu melibatkan atau berharap program CSR. Karena itu selalu disepakati bahwa salah satu tujuan akhir dari program-program kegiatan CSR adalah masyarakat yang berdaya.
Hanya saja dalam implementasinya tak jarang pemberdayaan masyarakat melalui program CSR terkendala karena masalah komunikasi antara pengelola kegiatan dengan masyarakat yang menjadi sasaran program kegiatan. Masalah komunikasi ini beragam, dari soal isi atau pesan komunikasi terkait program, penyampai komunikasi, hingga media komunikasinya.

Berangkat dari hal itu, maka dipandang perlu adanya strategi komunikasi untuk program CSR dalam upaya pemberdayana masyarakat. Strategi komunikasi tersebut menjadi hal yang urgen dalam konteks membantu implementasi program CSR untuk pemberdayaan masyarakat.

Adapun rumusan masalah dalam tulisan ini adalah bagaimanakah hubungan CSR dengan pemberdayaan masyarakat dan bagaimanakah strategi komunikasi untuk program CSR dalam upaya pemberdayaan masyarakat? Tujuan penulisan ini adalah untuk mengetahui hubungan CSR dengan pemberdayaan 
masyarakat dan untuk mengetahui dan menganalisis strategi komunikasi program CSR dalam upaya pemberdayaan masyarakat.

\section{Metodologi}

Tulisan ini berjenis telaah pustaka yang disajikan secara diskriptif. Teknik pengumpulan datanya dilakukan dengan teknik data sekunder yang diperoleh melalui penelusuran buku-buku yang relevan, hasil penelitian yang terkait dengan topik tulisan, berita media massa, dan jurnal-jurnal yang relevan. Data-data yang diperoleh tersebut selanjutnya dianalisis dan dibahas dengan teknik kualitatif dengan pendiskripsian data-data yang diperoleh untuk menjawab permasalahan yang ada.

\section{Hasil dan Pembahasan}

$\begin{array}{rlr}\text { Soetomo } & \text { (2006) } & \text { menjelaskan } \\ \text { pemberdayaan } & \text { atau pembangunan }\end{array}$
masyarakat adalah perubahan sosial yang berencana, baik dalam bidang ekonomi, teknologi, sosial maupun politik. Pembangunan masyarakat dalam arti luas juga dapat berarti proses pembangunan yang lebih memberikan fokus perhatian pada aspek/manusia dan masyarakatnya. Dalam arti sempit, pembangunan masyarakat berarti perubahan sosial berencana pada suatu lokalitas tertentu.

Pemberdayaan juga diartikan sebagai sebuah proses dengan mana orang menjadi cukup kuat untuk berpartisipasi dalam, berbagi pengontrolan, mempengaruhi kejadian-kejadian serta lembaga-lembaga yang mempengaruhi kehidupannya. Pemberdayaan menekankan bahwa orang memperoleh keterampilan, pengetahuan, dan kekuasaan yang cukup untuk mempengaruhi kehidupannya dan kehidupan orang lain yang menjadi perhatiannya ( Parson dalam Suharto; 2004).

Menurut Ambadar (2008), salah satu yang menonjol dari praktik CSR di Indonesia adalah penekanan pada aspek pemberdayaan masyarakat (community develompent). Meskipun CSR bukan semata-mata merupakan community development, namun hal ini memang sangat sesuai dengan kondisi dan kebutuhan masyarakat kita, yang masih bergelut dengan kemiskinan serta pengangguran dan rendahnya kualitas pendidikan dan kesehatan yang menjadi penyebab utama sulitnya memutus rantai kemiskinan. Maka CSR sebagai sebuah konsep yang berubah dan tumbuh sesuai dengan perkembangan dunia usaha dan kebutuhan masyarakat bisa menjadi salah satu jawaban.

Tahapan pemberdayaan masyarakat itu sendiri menurut Subejo dan Supriyanto (2004) dimulai dari proses seleksi lokasi sampai dengan pemandirian masyarakat. 
Secara rinci masing-masing tahap tersebut adalah sebagai berikut:

Tahap 1. Seleksi lokasi

Tahap 2. Sosialisasi pemberdayaan masyarakat

Tahap 3. Proses pemberdayaan masyarakat, yang dibagi ke dalam beberapa kegiatan:

- Kajian keadaan pedesaan partisipatif

- Pengembangan kelompok

- Penyusunan rencana dan pelaksanaan kegiatan

- Monitoring dan evaluasi partisipatif Tahap 4. Pemandirian Masyarakat

Seleksi lokasi dilakukan sesuai dengan kriteria yang disepakati oleh lembaga, pihak-pihak terkait dan masyarakat. Penetapan kriteria penting agar tujuan lembaga dalam pemberdayaan masyarakat akan tercapai serta pemilihan lokasi dilakukan sebaik mungkin. Sedangkan sosialisasi pemberdayaan masyarakat dilakukan untuk menciptakan komunikasi serta dialog dengan masyarakat. Sosialisasi ini membantu untuk meningkatkan pengertian masyarakat dan pihak terkait tentang program. Proses sosialisasi sangat menetukan ketertarikan masyarakat untuk berperan dan terlibat dalam program.

Salah satu tujuan CSR adalah mewujudkan masyarakat yang berdaya. Artinya, semua kegiatan CSR harus diarahkan terhadap upaya-upaya pemberdayaan masyarakat. Tapi, meski perusahaan sudah melakukan kegiatan CSR, ternyata pemberdayaan masyarakat masih sulit diwujudkan. Ini tidak terlepas dari model CSR yang sifatnya masih lebih untuk perbuatan amal daripada menciptakan kegiatan produktif. Dalam artian masyarakat masih sering hanya diberikan ikan, tapi bukan pancing. Diberi uang dan bantuan, bukan keterampilan atau skill. Alhasil, masyarakat justru mengalami ketergantungan, bukan berdaya.

Model-model kegiatan CSR seperti itu jelas belum efektif dalam mewujudkan pemberdayaan masyarakat. Makanya, harus ada alternatif model CSR lainnya yang diyakini bisa lebih efektif mewujudkan masyarakat yang berdaya.

Menurut Ife dan Tesoriero (2008), setidaknya ada enam dimensi pengembangan atau pemberdayaan masyarakat dan kesemuanya berinteraksi satu dengan lainnya dalam bentuk-bentuk yang kompleks. Keenam dimensi tersebut yaitu; pengembangan sosial, pengembangan ekonomi, pengembangan politik, pengembangan budaya, pengembangan lingkungan, dan pengembangan personal/ spiritual.

Dari model pelaksananya, program CSR bisa mengikuti model PerusahaanMasyarakat atau Model Perusahaan-Pihak Ketiga-Masyarakat. Pihak ketiga dalam hal 
ini bisa berupa yayasan atau bahkan institusi perguruan tinggi atau tegasnya setingkat jurusan atau departemen yang ada di fakultas (Siagian dan Suriadi 2010).

Kemudian pengembangan skill dan pendidikan sumber daya manusia lokal juga harus dilakukan. Untuk dapat menyesuaikan kemampuan di era ini, masyarakat harus dapat melakukan perubahan yang lebih kompetitif dengan melakukan peningkatan pendidikan dan keterampilannya untuk menjadi masyarakat yang tajam dalam menangkap peluang yang berorientasi pada masa depan (Widjajanti 2011).

Hal ini sejalan juga dengan hasil penelitian Bahri (2010) yang menyebutkan program pembelajaran life skill dengan strategi belajar partisipatif dan mengintegrasikan dengan kecakapan hidup yang dimiliki masing-masing anggota masyarakat akan membantu upaya pemberdayaan masyarakat.

Proses pemberdayaaan masyarakat dimaksudkan untuk meningkatkan kemampuan dan kemandirian masyarakat dalam meningkatkan taraf hidupnya lainnya yang diyakini bisa lebih efektif mewujudkan masyarakat yang berdaya.

Untuk mewujudkan pemberdayaan masyarakat melalui program CSR diperlukan peran strategi komunikasi. Strategi komunikasi merupakan panduan dari perencanaan komunikasi (communication planning) dan manajemen (communications management) untuk mencapai suatu tujuan. Untuk mencapai tujuan tersebut strategi komunikasi harus dapat menunjukkan bagaimana operasionalnya secara teknis harus dilakukan, dalam arti kata bahwa pendekatan (approach) bisa berbeda sewaktu-waktu tergantung dari situasi dan kondisi (Effendy, 2003).

Isi pesan komunikasi CSR terdiri dari dua kelompok yaitu external disclosure (meliputi lingkungan dan keterlibatan dalam komunitas) dan internal disclosure (meliputi sumber daya manusia serta produk dan pelanggan). Empat kategori pengungkapan atau komunikasi CSR, yakni Human resources disclosure, Products and customer disclosure, Enviromental disclosure dan Community involvement (Branco dan Rodrigues dalam Rusdianto, 2013).

Perusahaan yang melaksanakan kegiatan CSR perlu meningkatkan pemahaman mengenai implementasi komunikasi CSR. Komunikasi CSR menjadi bagian investasi bagi masa depan perusahaan. Kondisi bisnis saat ini menganggap komunikasi CSR sangat penting untuk masa depan perusahaan (Bortree, 2014).

Podnar (2008) mengatakan bahwa komunikasi CSR adalah suatu proses mengantisipasi harapan pemangku 
kepentingan, artikulasi kebijakan CSR dan mengelola berbagai media komunikasi untuk memberikan informasi yang benar dan transparan tentang integrasi merek perusahaan atau operasi bisnis, sosial dan masalah lingkungan, dan interaksi dengan pemangku kepentingan.

Strategi komunikasi CSR untuk pemberdayaan masyarakat bisa diartikan sebagai suatu cara atau teknik dalam proses pengkomunikasian pesan berupa kegiatan sosial, ekonomi, dan lingkungan yang dilakukan oleh perusahaan terhadap masyarakat sekitar dan stake holders dengan pemanfaatan berbagai media dengan mengharapkan adanya berbagai dampak yang bertujuan untuk pemberdayaan masyarakat.

Strategi komunikasi menjadi bagian penting bagi perusahaan dalam pengelolaan berbagai program kegiatan CSR. Kegiatan CSR yang telah diterapkan harus dikomunikasikan dengan baik sebagai bentuk tanggung jawab kepada pemangku kepentingan dan masyarakat, serta untuk target pemberdayaan masyarakat.

Dalam melaksanakan strategi komunikasi, pihak perusahaan bisa melakukan dengan komunikasi massa. Lewat komunikasi massa, perusahaan harus mampu menyajikan pesan-pesan komunikasi CSR. Pesan itu tentu berupa kegiatan CSR di bidang sosial dan ekonomi dengan masing-masing penjabarannya untuk pemberdayaan masyarakat. Pesan-pesan tersebut dapat disampaikan dalam berbagai bentuk, seperti social report, brosur, leaflet, website, iklan, berita, dan saluran komunikasi lainnya seperti media online dan sosial media.

Dalam strategi komunikasinya, perusahaan juga harus memilih media apa untuk mengomunikasikan kegiatan CSRnya. Media yang bisa jadi pilihan antara lain dokumen resmi, seperti laporan berkelanjutan yang diterbitkan setiap akhir tahun dan siaran pers. Selain itu, media lainnya adalah TV, majalah, koran, serta iklan di billboard atau dalam kemasan produk, termasuk pemanfaatan sosial media.

Selain itu, strategi komunikasi lainnya adalah dengan memanfaatkan komunikasi antarbudaya. Komunikasi antarbudaya (Intercultural Communication) adalah proses pertukaran pikiran dan makna antara orang-orang berbeda budaya (Mulyana, 2004).

$$
\text { Menurut Liliweri }
$$
komunikasi antarbudaya adalah menambah kata budaya ke dalam pernyataan "komunikasi antara dua orang/lebih yang berbeda latar belakang kebudayaan". Beberapa ahli komunikasi antarbudaya mengemukakakn pendapatnya tentang definisi komunikasi antarbudaya yang 
intinya dalah komunikasi antara orangorang yang berbeda kebudayaannya, misalnya antara suku bangsa, etnik, ras dan kelas sosial.

Beberapa unsur dalam proses komunikasi antarbudaya yang harus diperhatikan adalah komunikator (pengirim pesan), komunikan (penerima pesan), pesan (isi atau konten), media (saluran), efek dan umpan balik, dan suasana (setting dan konteks). Pihak perusahaan harus memahami unsur-unsur ini ketika melakukan strategi komunikasi dalma melaksanakan CSR untuk pemberdayaan masyarakat.

Di sisi lain, pelaku pemberdayaan masyarakat, dalam hal ini individu atau kelompok yang menjadi penanggung jawab dalam kegiatan pemberdayaan masyarakat harus memahami komunikasi dan strategi komunikasi. Mereka harus memanfaatkan komunikasi yang ada, baik komunikasi massa maupun komunikasi antarbudaya.

Pelaku pemberdayaan masyarakat harus membantu pihak perusahaan dalam rangka memilih media massa, menetapkan isi, pesan, dan juga membuat setting agar pelaksanaan pemberdayaan lebih efesien dan efektif. Kemudian tak kalah pentingnya adalah dengan menerapkan komunikasi antarbudaya, karena budaya dan suku bangsa yang ada di tengah masyarakat kemungkinan akan berbeda.
Kedua bentuk komunikasi ini sangat relevan untuk mendukung implementasi program CSR dalam rangka pemberdayaan masyarakat. Di sinilah diharapkan kejelian pihak perusahaan dan pelaku pemberdayaan masyarakat untuk menerapkan strategi komunikasinya. Harus dipahami juga salah satu keberhasilan program CSR untuk memberdayakan masyarakat ada pada aspek penggunaan komunikasi.

\section{Penutup}

Program CSR tak bisa dilepaskan dari pemberdayaan masyarakat. Tujuan CSR salah satunya adalah untuk mewujudkan masyarakat berdaya, khususnya masyarakat yang ada di sekitar perusahaan.

Dalam melaksanakan kegiatan CSR untuk pemberdayaan masyarakat, peran strategy komunikasi sangat diharapkan. Strategi komunikasi yang relevan antara lain adalah lewat komunikasi massa dan komunikasi antarbudaya. Dengan pengunaan dua strategi komunikasi ini diharapkan program-program CSR untuk pemberdayaan masyarakat lebih efektif dan efesien.

\section{Daftar Pustaka}

Ambadar, J.2008. Corporate Social Responsibility dalam Praktik di Indonesia. Edisi 1, Penerbit Elex Media Computindo. 
Bahri, Syaiful, 2010, Solusi Praktis Pengentasan Kemiskinan Melalui Pelatihan Keterampilan Layak Jual: Studi Deskreptif di Kelurahan Martubung Kecamatan Medan Labuhan. Akademia 12, Medan.

Bortree, D, S, 2014, The state of csr communication research: a summary and future direction, Public Relations Journal, 8 (3), hlm. 1-8.

Effendy, O, 2003, Dimensi - dimensi komunikasi, Alumni, Bandung.

fe, J dan Tesoriero, F. 2008. Alternatif Pengembangan Masyarakat di Era Globalisasi: Community Development. Yogyakarta: Pustaka Pelajar.

Liliweri, Alo, 2003, Dasar-Dasar Komunikasi Antar Budaya, Pustaka Pelajar, Yogyakarta.

Mulyana, Deddy, 2004, Komunikasi Efektif Suatu Pendekatan Lintas Budaya, Remaja Rosdakarya, Bandung

Podnar, K. 2008. Communicating corporate social responsibility. Journal of Marketing Communications, 14(2), 75-81.
Rusdianto, U, 2013, CSR communicatons a framework for PR practicioners, Graha Ilmu, Yogyakarta.

Siagian, Matias \& Suriadi, Agus. 2010. Tanggung Jawab Sosial PerusahaanCSR Perspektif Pekerjaan Sosial. Medan: FISIP USU Press.

Soetomo. 2006. Strategi-strategi pembangunan masyarakat. Pustaka Pelajar.

Subejo dan Supriyanto, 2004, Metodologi Pendekatan Pemberdayaan Masyarakat, Short paper pada Kuliah Intensif Pemberdayaan Masyarakat Pedesaan, Studyon Rural Empowerment (SORem)--Dewan Mahasiswa Fak. Pertanian UGM tanggal 16 Mei 2004.

Suharto, E. 2008, February. Corporate Social Responsibility: What is and Benefit for Corporate. In Makalah Seminar, Februari.

2004. Kemiskinan dan keberfungsian sosial: studi kasus rumah tangga miskin di Indonesia. Bandung: STKSPress.

Widjajanti, K. 2011. Model pemberdayaan masyarakat. 

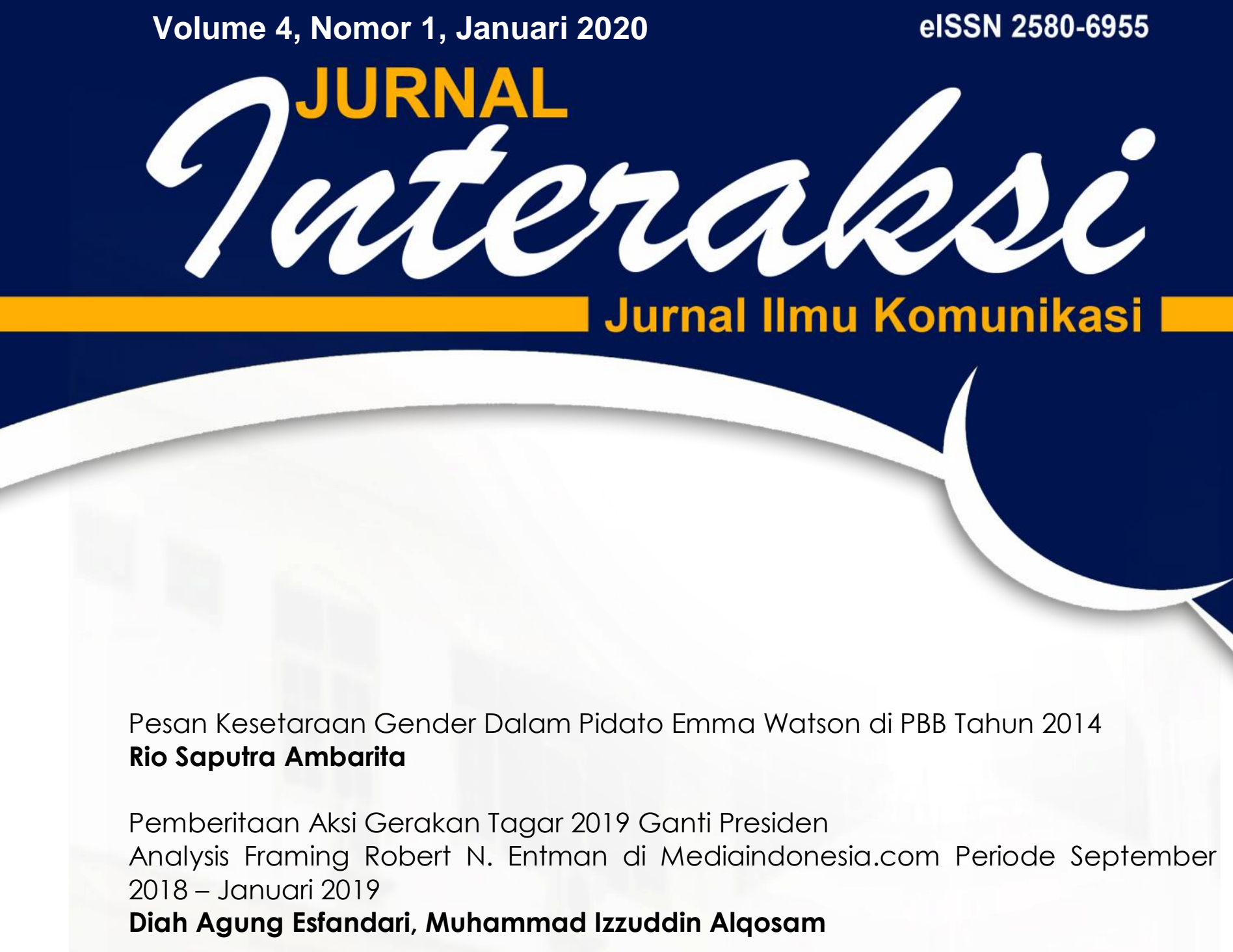

Branding Dan Positioning Identitas Budaya Indonesia Dalam Pesan Iklan TV Komersial Bejo Bintang Toedjoe Jahe Merah

Agus Hermanto, Sa'diah El Adawiyah

Identifikasi Faktor-Faktor Yang Mempengaruhi Minat Berkunjung Ke Olivier Café, Jakarta

\section{Tashia Tariq}

Studi Analisis Isi Pesan Dakwah Dalam Media Sosial Instagram @dakwah_tauhid Agus Triyono, Nifsya Khaira Marhuda

Relasi Politik, Bullying dan Etika Mengenai Isu "Muslim Uighur" di Media sosial Yofiendi Indah Indainanto

Breaking Down "Firewall" among Public Relations and Journalism Jamroji, Nasrullah

Strategi Komunikasi untuk Program Corporate Social Responsibility dalam Pemberdayaan Masyarakat

Arifin Saleh, Mislan Sihite 


\section{Turetralesi Jurnal IImu Komunikasi}

Jurnal Interaksi diterbitkan oleh Universitas Muhammadiyah Sumatera Utara (UMSU) bekerjasama dengan Asosiasi Pendidikan Ilmu Komunikasi Perguruan Tinggi Muhammadiyah (APIK PTM) yang terbit dua kali d alam setahun pada bulan Januari dan Juli. Terbit pertama kali pada bulan Januari 2017.

Jurnal Interaksi memuat tulisan yang difokuskan pada pemikiran kontemporer Ilmu Komunikasi, Media, Teknologi Komunikasi, Komunikasi Terapan, dalam berbagai sudut pandang atau perspektif. 


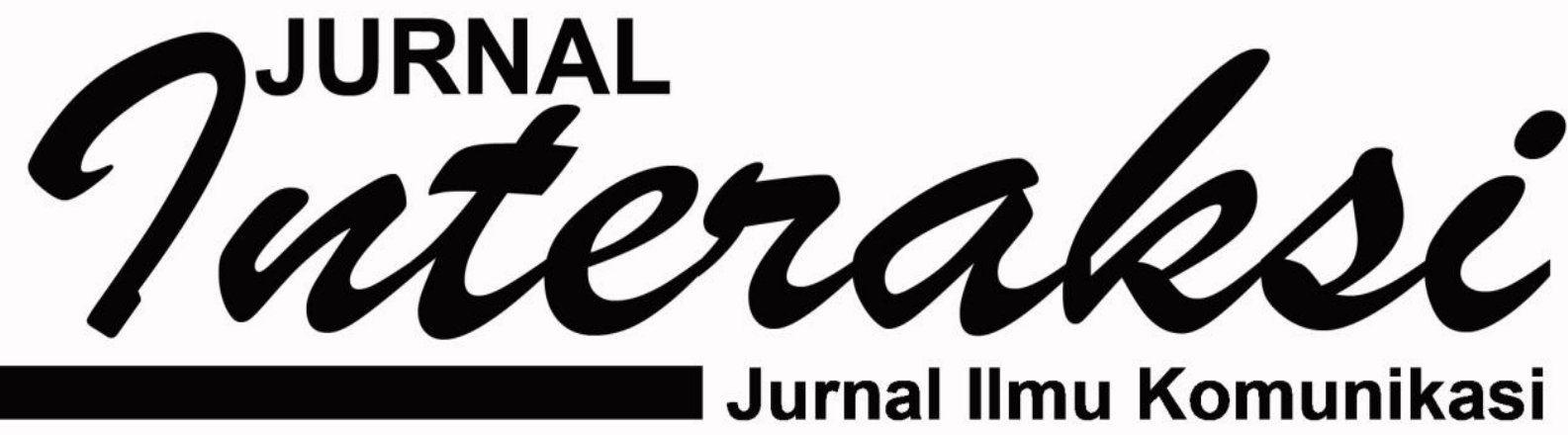

Pesan Kesetaraan Gender Dalam Pidato Emma Watson di PBB Tahun 2014 Rio Saputra Ambarita

Pemberitaan Aksi Gerakan Tagar 2019 Ganti Presiden

Analysis Framing Robert N. Entman di Mediaindonesia.com Periode September 2018 - Januari 2019

Diah Agung Esfandari, Muhammad Izzuddin Alqosam

Branding Dan Positioning Identitas Budaya Indonesia Dalam Pesan Iklan TV Komersial Bejo Bintang Toedjoe Jahe Merah

Agus Hermanto, Sa'diah El Adawiyah

Identifikasi Faktor-Faktor Yang Mempengaruhi Minat Berkunjung Ke Olivier Café, Jakarta

Tashia Tariq

Studi Analisis Isi Pesan Dakwah Dalam Media Sosial Instagram @dakwah_tauhid Agus Triyono, Nifsya Khaira Marhuda

Relasi Politik, Bullying dan Etika Mengenai Isu "Muslim Uighur" di Media sosial Yofiendi Indah Indainanto

Breaking Down "Firewall" among Public Relations and Journalism Jamroji, Nasrullah

Strategi Komunikasi untuk Program Corporate Social Responsibility dalam Pemberdayaan Masyarakat

Arifin Saleh, Mislan Sihite 


\section{Tuteralese}

Volume 4 Nomor 1 Edisi Januari 2020

\section{DAFTAR ISI}

\section{$1-11$}

Pesan Kesetaraan Gender Dalam Pidato Emma Watson di PBB Tahun 2014 Rio Saputra Ambarita

\section{$12-23$}

Pemberitaan Aksi Gerakan Tagar 2019 Ganti Presiden

Analysis Framing Robert N. Entman di Mediaindonesia.com Periode September 2018 - Januari 2019

\section{Diah Agung Esfandari, Muhammad Izzuddin Alqosam}

\section{4-40}

Branding Dan Positioning Identitas Budaya Indonesia Dalam Pesan Iklan TV Komersial Bejo Bintang Toedjoe Jahe Merah

Agus Hermanto, Sa'diah El Adawiyah

\section{1-49}

Identifikasi Faktor-Faktor Yang Mempengaruhi Minat Berkunjung Ke Olivier Café, Jakarta

\section{Tashia Taria}

\section{0-67}

Studi Analisis Isi Pesan Dakwah Dalam Media Sosial Instagram @dakwah_tauhid Agus Triyono, Nifsya Khaira Marhuda

\section{8-85}

Relasi Politik, Bullying dan Etika Mengenai Isu "Muslim Uighur" di Media sosial Yofiendi Indah Indainanto

\section{6-97}

Breaking Down "Firewall" among Public Relations and Journalism Jamroji, Nasrullah

98-105

Strategi Komunikasi untuk Program Corporate Social Responsibility dalam Pemberdayaan Masyarakat

Arifin Saleh, Mislan Sihite 